\title{
NOTES ON SOME REMARKABLE TASMANIAN INVERTEBRATES.
}

\author{
By Arthur M. Lea, F.E.S., etc. \\ (Read July 8th, 1902.)
}

(Issued July 23rd, 1902.)

\section{(Plate.)}

Under the above heading 1 propose from time to time to give notes on some remarkable Tasmanian insects, ard probably other invertebrate forms of life. The notes, when. ever possible, will be illustrated with sketches. The present deals with one of the walking-stick insects, being the first record of the occurrence of this remarkable family (Phasmidee) in Tasmania.

\section{Acrophylla tasmaniensis, n. sp.}

Of a dingy, testaceous brown; wings black, costal area on its basal half variegated with yellow and black, the outer half testaceous brown. Antennæ very finely pubescent. EHead without granules, anterior half wrinkled; ocelli absent. Antennæ thin, joints 23 in number, first the length of second and third combined, second slightly more than half the length of third, terininal joint almost the length of the three preceding combined. Prothorax not quite as long as head, surface wrinkled, and with a few very small granules. Mesothorax more than twice the length of prothorax and head combined, with small scattered spines. Tegmina nearly three times as long as wide, apex rounded. concealing about half the length of the folded wings. Wings about once and one-half as long as wide, the costal area about one-third of the whole. Abdomen about two-thirds of the total length of body, fifth seoment inflated on each side posteriorly, sixth raised in middle of base; anal styles long, parallel-sided, somewhat wars, apex rounded. Mieso- and metasternum with a few small granules; ovipositor longer than three apical segments. Legrs long and thin, anterior femora serrate, the others with small spines, of which the largest are on the middle of the upper surface ; tibiæ feebly spinose (the anterior almost bare of spines), the intermediate each with a large tooth on the upper surface before the middle.

Lengths in millimetres:-Head, $8\left[* 5 \frac{1}{2}\right]$; prothorax, 7 [5]; mesothorax, 31 [19]; metathorax, 16 [13]; abdomen (exclusive of anal styles), 89 [54]; antennæ, $26\left[11 \frac{1}{2}\right]$; anal styles, 20 [8]; anterior femora, 39 [23], tibiæ, 42 [26], tarsi, 16 [11]; intermediate femora, 28 [18], tibiæ, 30 [18],

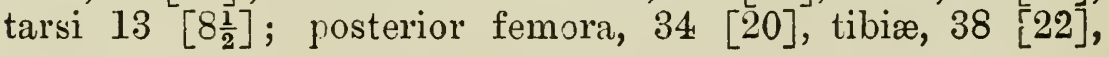


tarsi, 15 [10]; tegmina, $19\left[2 \frac{1}{2}\right]$; wings, 20 [3]; total length (including anal styles), $170 \uparrow[102]$.

Habitat, Burnie.

(Presented to the Tasmanian Museum by Miss Dora Shoobridge.)

'The specimen (a female) appears to be somewhat discoloured, as there are traces of green on the mesothorax under surface of tegmina and anal styles; the ovipositor is also somewhat damaged. The large tooth of the intermediate tibix is single on the left, but doubre on the right.

The species appears to be allied to $A$. chronus (Westwood, Cat logue of Phasmidæ, p. 114, supplementary plate $V$., fig. 2), but should be distinct on account of the posteriorly inflated fourth abdominal segment and large teeth of the intermediate tibiæ. From Westrood's figure it differs in the shape of the tegmina and length of wings; the latter, however, are described as being very variable in length. The colours of the wings are very different to those given for chronus, the membranous portion being entirely black, whilst in the figure it is drawn (and also so described) as being variegated. The serrations and spines of the legs are also very different to those on Westwood's figure.

An immature specimen, evidently belonging to this species, was presented to the Department of Agriculture by $\mathrm{Mr}$. W. C. Weymouth. Its antennæ consist of but 24 joints each. The spines and serrations of the legs are the same as in the type, even to the peculiar dentition of the intermediate tibiæ. The tegmina ond wings are rery small, of almost equal size and shape, and of a dull greenish yellow, with thickened edges, they look like scales. The general colour of the body is rather paler than that of the type.

* The lengths given in brackets are those of the immature specimen.

$t$ It is, therefore, the longest (although not the largest) insect at present known. to occur in Tasmania. 
